\title{
DESAIN RUMAH TINGGAL YANG RAMAH LINGKUNGAN UNTUK IKLIM TROPIS
}

\author{
Hendra Simbolon ${ }^{1}$, Irma Novrianty Nasution ${ }^{2}$ \\ ${ }^{1}$ Alumni Program Studi D-3 Teknik Sipil, Fakultas Teknik UNIMED \\ ${ }^{2}$ Dosen Pengajar Jurusan Pendidikan Teknik Bangunan, Fakultas Teknik UNIMED \\ (xhendrapyo@gmail.com) \\ (irmanovri@gmail.com)
}

\begin{abstract}
Diterima : 3 Maret 2017
Disetujui $\quad: 17$ April 2017
\end{abstract}

\begin{abstract}
ABSTRAK
Kebutuhan manusia akan rumah tinggal sebagai kebutuhan primer tidak dapat dipandang sebelah mata. Sekarang ini, kebanyakan rumah tinggal dibangun hanya berfokus pada aspek keindahannya saja tanpa mempertimbangkan kondisi lingkungan dan iklim pada lokasi rencana rumah tinggal akan dibangun. Penulisan karya ilmiah ini bertujuan untuk mendesain rumah tinggal yang ramah lingkungan untuk iklim tropis ditinjau dari aspek termalnya (ventilasi alami dan pencahayaan alami). Desain rumah tinggal rumah ramah lingkungan dibuat dengan memperhatikan aspek lingkungannya, seperti kondisi site existing, peredaran matahari, pergerakan angin, dan aspek lingkungan lainnya. Semua aspek tersebut dianalisis untuk memenuhi kebutuhan rumah tinggal akan aspek kenyamanan termal. Untuk mencapainya dapat dilakungan perancangan secara pasif dengan metode ventiasi alami dan pencahayaan alami yang diterapkan pada desain bangunan. Luasan minimal ventilasi alami dalam suatu ruangan adalah 10 \% dari luas lantai ruang tersebut. Dari hasil analisa didapat orientasi bangunan terbaik menghadap arah timur-barat, untuk orientasi bukaan terbaik menghadap utara dan selatan, pada arah ini cahaya matahari bersinar stabil sepanjang hari. Untuk mengatasi radiasi matahari yang tinggi, pada area sekitar bangunan ditanam vegeasi dengan jenis pohon yang rindang dan menyejukkan. Adapun untuk memberikan efek dingin pada ruangan tipe bukaan/jendela yang sesuai dari hasil analisa adalah jendela tipe pivot(berporos) untuk memaksimalkan masuknya angin pada ruang. Untuk mengatasi kondisi kelembapan yang tinggi, dibuat ventilasi bawah yang berada tepat pada bawah jendela, kemudian pada adap yang memiliki bidang datar ditambakan ventiasi untuk mengeluarkan udara panas di ruang antara atap dan plafon. Untuk memberikan kesejukan yang alami pada bangunan, di buat jarak antar bangunan dengan bangunan eksisting agar angin dapat bergerak bebas di area bangunan.
\end{abstract}

Kata Kunci : Pencahayaan, Ramah Lingkungan, Rumah Tinggal, Ventilasi

\section{Pendahuluan}

Seiring dengan bertambahnya penduduk sejalan pula dengan petumbuhan bangunan sebagai tempat bernaung dari iklim luar yang ekstrim. Bangunan yang berfungsi sebagai tempat tempat tinggal biasanya disebut dengan rumah. Kebutuhan manusia akan rumah tinggal tidak bisa dipandang sebelah mata saja, karena ini merupakan kebutuhan primer setiap manusia. Oleh karenanya, dibutuhkan perencanaan yang baik agar pembangunan rumah tinggal dapat memberikan kenyamanan bagi penghuninya. 
Menurut Karyono (2013), rumah tinggal yang baik harus mampu memodifikasi iklim luar yang tidak nyaman menjadi iklim dalam yang nyaman bagi penghuninya . Faktor penting untuk membangun perlindungan terhadap iklim yang tidak nyaman tersebut yaitu melalui pencahayaan, suhu, kelembaban udara, dan sebagainya.Menurut Peraturan Menteri Negara Lingkungan Hidup Nomor 8 Tahun 2010, bangunan ramah lingkungan (green building) adalah suatu bangunan yang menerapkan prinsip lingkungan dalam perancangan, pembangunan, pengoperasian, dan pengelolaannya, serta merupakan aspek penting penanganan dampak perubahan iklim. Untuk mencapai bangunan ramah lingkungan tersebut dapat dilakukan perancangan secara pasif (alami), yaitu perancangan bangunan dengan mempertimbangkan faktor iklim, sifat fisika bangunan dan variabel perancangan bangunan lainnya seperti orientasi bangunan, bentuk, peneduh matahari dan sebagainya (Soegijanto, 1999:1). Perancangan secara pasif ini sering juga disebut perancangan secara alami, misalnya perancangan termal alami termasuk ventilasi alami serta pencahayaan alami.

Berdasarkan pemikiran dan permasalahan yang telah diuraian di atas, maka penulis akan memaparkan lebih dalam pembahasan tentang perencanaan bangunan yang ramah lingkungan di daerah beriklim tropis dari aspek perancangan termal yang alami.

Pembangunan rumah tinggal bertumbuh dengan pesatnya. Butuh perencanaan dengan baik agar fungsi rumah tinggal sebagai tempat bernaung dari iklim luar yang tidak nyaman menjadi iklim dalam yang nyaman agar dapat tercapai. Indonesia merupakan negara dengan iklim tropis, dimana curah hujan tinggi, cahaya matahari tinggi, kelembapan tinggi dan suhu yang relatif tinggi. Aspek termal (suhu) merupakan hal yang paling dominan yang perlu dipenuhi pada bangunan tropis. Oleh karena itu, dibutuhkan desain rumah tinggal yang mampu menjawab menjawab permasalahan iklim tropis yang ramah lingkungan dan hemat energi.

Berdasarkan identifikasi masalah diatas, maka dibuat batasan masalah yaitu sebagai berikut :

a. Kriteria desain rumah tinggal ramah lingkungan untuk iklim tropis dari segi aspek termal (suhu). b. Desain bangunan dibatasi pada orientasi bangunan, organisasi ruang, serta model dan dimensi ventilasi.

Berdasarkan batasan masalah di atas, maka dirumuskan beberapa masalah antara lain sebagai berikut :

a. Bagaimana desain rumah tinggal yang ramah tinggal lingkungan untuk iklim tropis?

b. Apa kriteria desain rumah tinggal yang ramah lingkungan untuk iklim tropis?

\section{Kajian Teori}

\subsection{Pengertian Rumah Tinggal}

Rumah tinggal merupakan salah satu kebutuhan dasar bagi manusia (primer) disamping kebutuhan sandang dan pangan. Dikatakan sebagai kebutuhan dasar karena merupakan unsur yang harus dipenuhi guna menjamin kelangsungan hidup manusia.Rumah menjadi tempat berlindung dari cuaca dan lingkungan sekitar yang, menyatukan keluarga, meningkatkan tumbuh kembang manusia, dan menjadi bagian dari gaya hidup (Wicaksono, 2009:3). Rumah diharapkan mampu memberikan kenyamanan bagi penghuninya, baik itu secara psikis maupun fisik. Kenyamanan psikis berkaitan dengan aspek kepercayaan, agama, adat istiadat, dan sebagainya. Kenyaman psikis lebih bersifat kulitatif, yaitu suatu kesenangan secara jiwa. Adapun kenyamanan fisik lebih bersifat luas dan dapat diukur secara kuantitatif. Secara umum kenyamanan fisik dapat dibagi menjadi empat jenis, yakni kenyamanan spatial (ruang), kenyamanan visual (pengelihatan), kenyamanan audial (pendengaran) dan kenyamanan thermal (termis/suhu) (Karyono, 2013:107).

\subsection{Perencanaan Rumah Tinggal}

Sebelum membangun rumah tinggal, sebaiknya dilakukan perencanaan terlebih dahulu agar rumah yang terbangun nantinya sesuai dengan keinginan si penghuninya dan memenuhi persyaratan dasar rumah yang baik.

Menurut Amin dkk (2014:8), dalam merencanakan sebuah bangunan rumah tinggal, perancangan denah sangatlah 
penting. Melalui gambar denah tersebut penghuni dapat membaca model, bentuk, atau wujud yang akan dibangun. Ada beberapa pertimbangan dalam merancang denah agar fungsinya dapat dicapai dengan maksimal:
a. Pertimbangan Jumlah Penghuni Rumah
b. Kebutuhan Ruang Penghuni Rumah
c. Fungsi Ruang
d. Kenyamanan
e. Keamanan
f. Nilai Estetika

\subsection{Kriteria Desain Rumah Ramah Lingkungan}

MenurutPeraturan Menteri Negara Lingkungan Hidup (2010), bangunan dapat dikategorikan sebagai bangunan ramah lingkungan apabila memenuhi kriteria berikut yaitu :
a. Menggunakan material bangunan yang ramah lingkungan.
b. Terdapat fasilitas, sarana, dan prasarana untuk konservasi sumber daya air dalam bangunan gedung.
c. Terdapat fasilitas, sarana, dan prasarana konservasi dan diversifikasi energi.

d. Menggunakan bahan yang bukan bahan perusak ozon dalam bangunan gedung.

e. Terdapat fasilitas, sarana, dan prasarana pengelolaan air limbah domestik pada bangunan gedung.

f. Terdapat fasilitas pemilahan sampah,

g. Memperhatikan aspek kesehatan bagi penghuni bangunan antara lain:

1) Melakukan pengelolaan sistem sirkulasi udara bersih;

2) Memaksimalkan penggunaan sinar matahari.

h. Terdapat fasilitas, sarana, dan prasarana pengelolaan tapak berkelanjutan.

i. Terdapat fasilitas, sarana, dan prasarana untuk mengantisipasi bencana alam.

j. Menggunakan material bangunan yang tahan terhadap iklim atau cuaca ekstrim intensitas hujan yang tinggi, kekeringan dan suhu tinggi

Menurut Frick dan Suskiyatmo

(1998:68), perencanaan eko-arsitektur berpedoman pada alam sebagai polanya, dengan persyaratan sebagai berikut:

a. Penyesuaian dengan alam setempat

b. Menghemat sumber energi alam yang tidak dapat diperbaharui dan mengirit penggunaan energi

c. Memelihara sumber lingkungan (udara, tanah, air)

d. Memelihara sumber dan memperbaiki peredaran alam

e. Mengurangi ketergantungan pada sistem pusat energi (listrik, air) dan limbah (air limbah, sampah)

f. Penghuni ikut seta aktif pada perancangan, pembangunan, dan pemeliharaan perumahan

g. Tempat kerja dan permukiman dekat

h. Kemungkinan penghuni menghasilkan sendiri kebutuhannya sehari-hari.

i. Menggunakan teknologi sederhana

\subsection{Desain Ventilasi Alami}

Menurut Istiqomah dan Hanas (2011:38), udara segar diperlukan rumah untuk menjaga suhu dan kelembapan udara dalam ruangan. Sebaiknya suhu udara harus lebih rendah paling sedikit 4 ${ }^{0} \mathrm{C}$ dari suhu udara di luar ruangan. Umumnya suhu kamar $22^{\circ} \mathrm{C}-30^{\circ} \mathrm{C}$ sudah cukup segar. Pergantian udara bersih untuk orang dewasa adalah 33 $\mathrm{m}^{3}$ /orang/jam dengan kelembapan udara berkisar $60 \%$ optimum. Ventilasi yang baik dalam ruangan harus memenuhi beberapa syarat diantaranya (Istiqomah dan Hanas, 2011:38) :

a. Luas lubang ventilasi tetap minimum 5\% dari luas lantai ruangan. Sedangkan luas ventilasi insidentil (dapat dibuka dan ditutup) minimum 5\% dari luas lantai. Total menjadi minimal ventilasi dalam satu ruangan adalah $10 \%$ dari luas ruangan tersebut dan maksimal $20 \%$ dari luas ruangan tersebut. Idealnya sebuah ruangan memiliki luas bukaan seluas $15 \%$ dari luas ruangan tersebut.

b. Udara yang masuk harus udara bersih, tidak tercemar oleh dari sampah atau dari pabrik, dari 
knalpot kendaraan, debu dan lainlain.

c. Aliran udara jangan menyebabkan orang masuk angin.

d. Aliran udara diusahakan cross ventilation menempatkan bukaan berhadapan antara dinding dalam ruangan.

e. Kelembapan udara dijaga jangan terlalu rendah (menyebabkan kulit kering dan bibir pecah-pecah) dan jangan pula terlalu tinggi (menyebabkan orang berkeringat).

Selain persyaratan yang telah dijelaskan sebelumnya, posisi sash (bingkai tempat kaca dipasang) juga akan memberikan pengaruh tehdapa besarnya ventilasi pada suatu ruangan (Ching dan Adams, 2008:281) :

a. Jendela Permanen, terdiri dari bingkai dan sash statis. Dengan nilai ventilasi $0 \%$
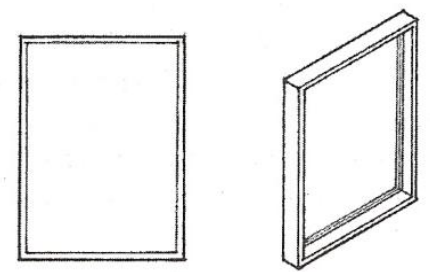

\section{Gambar 1 Jendela permanen, nilai ventilasi $0 \%$}

b. Jendela Ayun, mempunyai sashyang diberi engsel samping dan biasanya berayun keluar. Ketika dibuka sashmampu mengarahkan ventilasi secara penuh ke dalam ruang.
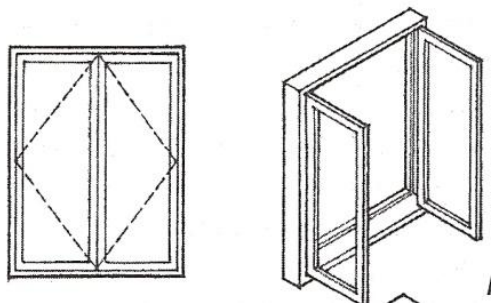

Gambar 2 Jendela ayun, nilai ventilasi $100 \%$

c. Jendela Awning dan Hopper, mempunyai sash yang berayun keluar pada engsel yang dipasang pada bagian atas atau bawah bingkai jendela. Ketika dibuka sashmampu mengarahkan ventilasi secara penuh.
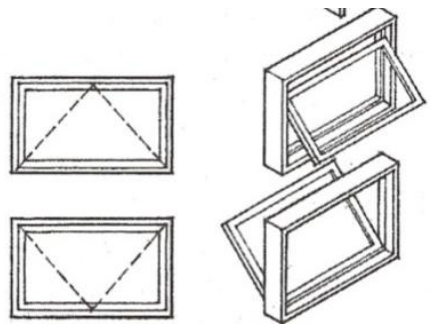

Gambar 3 Jendela awning dan hopper, nilai ventilasi $100 \%$

d. Jendela Geser, mempunyai dua sashatau lebih, di mana paling tidak terdapat satu sash geser sepanjang trek horizontal.
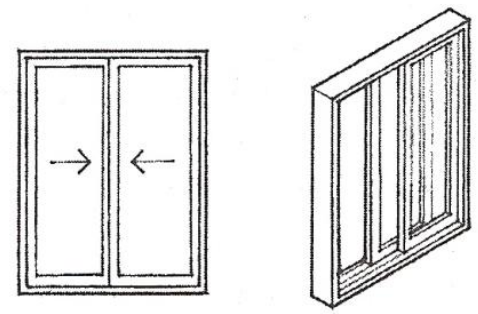

\section{Gambar 4 Jendela geserayun, nilai ventilasi $50 \%$}

e. Jendela Gantung Ganda, mempunyai dua sashyang bergeser vertikal, masing masing pada trek berbeda dan saling menutup area yang berbeda dari jendela. Jendela tipe ini mampu mengarahkan ventilasi dengan nilai $50 \%$.
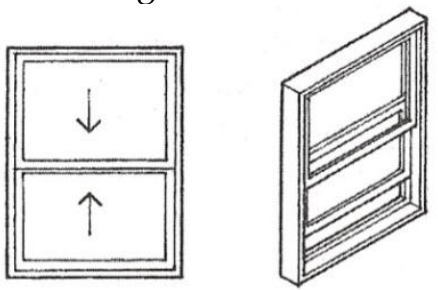

\section{Gambar 5 Jendela gantung ganda, nilai ventilasi $50 \%$}

f. Jendela Jalousi, mempunyai kisi louver kayu atau kaca horizontal yang bersumbu pada satu bingkai. Jalousi biasanya digunakan pada daerah beriklim sedang untuk mengendalikan ventiasi dan menghalangi padangan ke luar. 

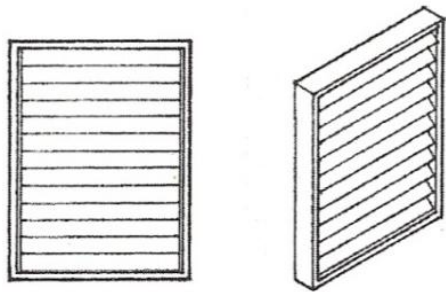

Gambar 6 Jendela jalousi, nilai ventilasi $100 \%$

g. Jendela Bersumbu, mempunyai sashyang dapat berputar secara $90^{\circ}$ atau $180^{\circ}$ pada sumbu horizontal atau vertikal pada atau dekat titik tengahnya. Sashbersumbu biasa digunakan pada bangunan berlantai banyak dengan AC dan jendela ini dioperasikan hanya ketika pembersihan , perawatan atau ventilasi darurat.'
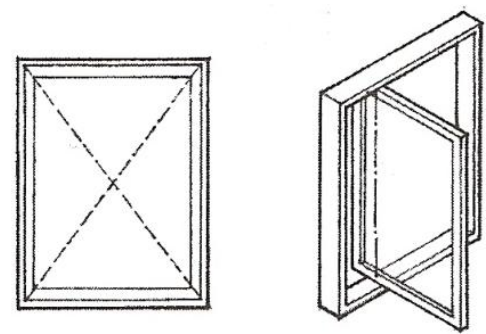

\section{Gambar 7 Jendela bersumbu, nilai ventilasi $\mathbf{1 0 0} \%$}

Menurut Lechner (2007:297), ada beberapa faktor yang menentukan pola aliran udara yang melewati suatu bangunan diantaranya adalah sebagai berikut:

a. Kondisi Tapak

Bangunan, tembok, atau vegetasi yang berbatasan dengan tapak akan memberikan pengaruh yang besar pada aliran udara yang melewati suatu bangunan.

b. Orientasi Jendela dan Arah Angin

Angin akan menghasilkan aliran yang maksimal ketika posisinya tegak lurus terhadap permukaan dan tekanannya akn berkurang $50 \%$ ketika angin tersebut ada pada kemiringan sekitar $45^{\circ}$. Namun, ventilasi ruang dalam akan sering lebih baik dengan angin miring karena menghasilkan turbelensi ruang dalam yang lebih besar.
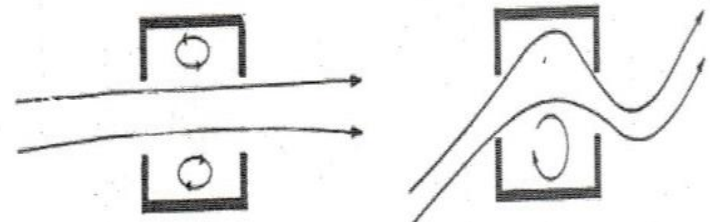

Gambar 8 Angin miring lebih baik dalam ventilasi suatu bangunan

c. Lokasi Jendela

Ventilasi-silang sangat efektif karena udara mengalir dari tekanan positif yang kuat ke area dengan tekanan negatif yang kuat pada dinding di depannya.
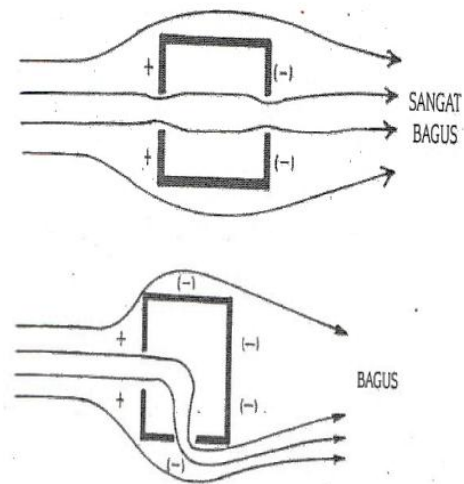

Gambar 9 Ventilasi silang antara jendela pada dinding di depannya merupakan kondisi yang ideal

d. Sirip Dinding

Sirip dinding (fin walls) dapat meningkatkan ventilasi melalui jendela yang terpasang pada sisi sama bangunan dengan cara mengubah ditribusi tekanannya.

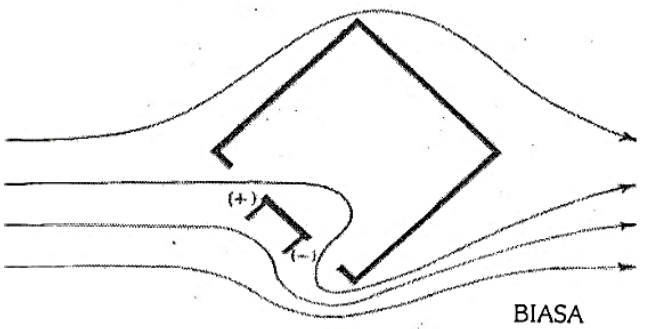

Gambar 10 Sirip dinding dapat meningkatkan ventilasi secara signifikan melalui jendela di dinding yang sama 
Overhang Horizoltal dan Aliran Udara

Overhang horizontal yang terletak

langsung di atas jendela akan menyebabkan arus udara menangkis ke bagian plafon karena overhang yang solid akan mencegah tekanan positif yang berada di atasnya dari proses penyeimbangan tekanan positif di bawah jendela.

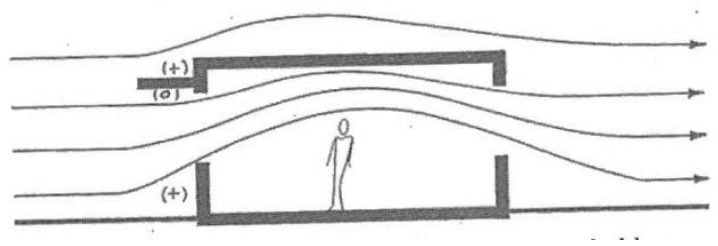

Gambar 11 Overhang horizontal yang solid akan menyebabkan udara terpantul ke atas

\subsection{Desain Pencahayaan Alami}

Menurut Manurung (2012), orientasi bangunan merupakan salah satu faktor yang mempengaruhi desain pencahayaan alami (daylighting design). Arah datangnya cahaya dan eksisting pada site (bangunan sekitar, pepohonan, dan kondisi lainnya) merupakan pertimbangan dalam menentukan orientasi bangunan. Orientasi bangunan harus disesuaikan dengan tujuan perancangan dan kebutuhan cahaya pada ruang tertentu. Pertimbangan ini mengacu pada kuantitas dan kualitas serta karakter yang berbeda pada berbagai arah masuknya cahaya.

Tujuan umum pencayaan alami yaitu menghasilkan cahaya berkualitas yang efisien serta meminimalkan silau langsung, lapisan pemantul, dan berlebihnya rasio tingkat terang. Umumnya luas total bukaan jendela pada sebuah ruang yang baik untuk pencahayaan alami adalah minimal 1/5 dari luas ruangan tersebut dan maksimal 1/10 dari lantai ruangan tersebut (Dora dan Poppy, 2011).

Atas dasar tujuan tersebut diperlukan strategi dalam merancang pencahayaan alami, berikut merupakan beberapa strategi dasar pencahayaan alami (Lechner, 2007:423) :
a. Orientasi
b. Pencahayaan Melalui Atap
c. Bentuk
d. Perencanaan Ruang
e. Warna

\subsection{Iklim Tropis di Indonesia}

Menurut Lippsmeier (1997:8), daerah tropis dibedakan ke dalam dua iklim utama, masing masing dua daerah sekunder dan dua daerah tambahan. Klasifikasi daerah ini dibuat berdasarkan tiga faktor atmosfir yang paling berpengaruh terhadap kesejahteraan kehidupan manusia yakni suhu, kadar kelembapan, dan gerakan udara.

Indonesia merupakan daerah yang secara umum memiliki iklim tropis lembap ditandai dengan kelembapan udara yang relatif tinggi (sering di atas 90 $\%)$, curah hujan yang tinggi, serta suhu tahunan di atas $20^{\circ} \mathrm{C}$, yang bisa meningkat menjadi $35^{\circ} \mathrm{C}$ pada musim panas. Namun ada beberapa daerah di Indonesia di mana curah hujannya amat sedikit seperti daerah Nusa Tenggara

Iklim tropis lembap sendiri dicirikan oleh beberapa faktor iklim (climatic factor) (Karyono, 2013:106) sebagai berikut:

a. Curah hujan tinggi sekitar 2000 - 3000 $\mathrm{mm} /$ tahun (Medan \pm 2000 $\mathrm{mm} /$ tahun atau rata-rata \pm 180 $\mathrm{mm} /$ bulan).

b. Radiasi matahari relatif tinggi sekitar 1500 hingga $2500 \mathrm{kWh} / \mathrm{m}^{2} /$ tahun (Medan $\pm 1800 \mathrm{kWh} / \mathrm{m}^{2} /$ tahun)

c. Suhu udara relatif tinggi untuk kota dan kawasan pantai atau dataran rendah (Medan antara $23^{\circ} \mathrm{C}$ hingga $34^{\circ} \mathrm{C}$ )

d. Kelembapan tinggi (Medan antara 65 hingga $94 \%$ )

e. Kecepatan angin relatif rendah (Medan rata-rata 2,4 m/s)

\section{Metodologi Penelitian}

\subsection{Persiapan}

Persiapan awal yang dilakukan untuk menunjang kelancaran Tugas Akhir adalah sebagai berikut :

a. Melengkapi studi pustaka berupa pengumpulan materi studi sebagai referensi.

b. Membuat site awal lokasi. 
c. Survey lokasi untuk mendapatkan gambaran umum rencana bangunan.

b. Pembuatan jadwal rencana penyusunan Tugas Akhir

\subsection{Lokasi}

Lokasi rencana bangunan yang akan dibahas dalam penelitian ini adalah di Jalan Rela Gang Danau Toba No. 5, Pancing, Medan. Pemilihan Lokasi tersebut dengan pertimbangan bahwa secara eksisting daerah tersebut merupakan daerah padat permukiman, sehingga akan mempunyai tantangan tersendiri dalam mendesain rumah tinggal yang ramah lingkungan.

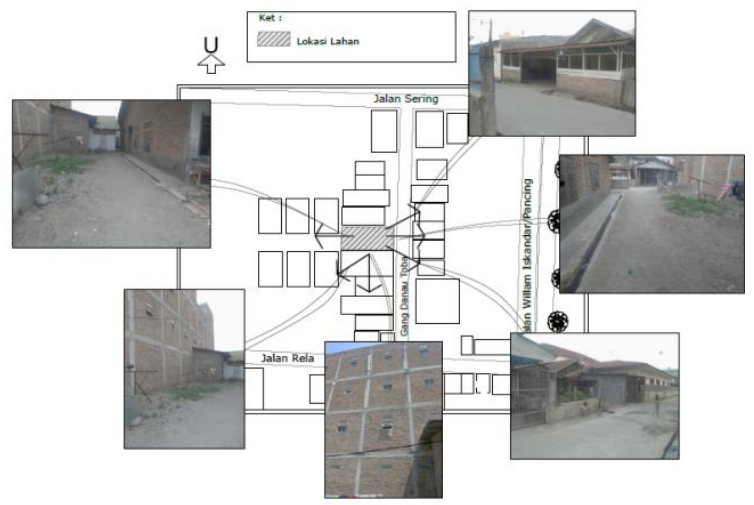

Gambar 12 Lokasi Rencana Bangunan

\section{Hasil dan Pembahasan}

\subsection{Data Awal}

Data awal yang dibutuhkan adalah data penghuni. Penghuni yang akan menempati rencana rumah tinggal terdiri dari 4 orang dengan detail sebgai berikut :

- Ayah : usia 48 tahun, profesi PNS.

- Ibu : usia 44 tahun, profesi ibu rumah tangga.

- Anak perempuan : usia 17 tahun, profesi siswi kelas 3 SMA.

- Anak laki-laki : usia 20 tahun, profesi mahasiswa semester 4 .

\section{1. $\quad$ Site Existing}

Lahan terletak di antara himpitan bangunan gedung (rumah tinggal dan kostkostan disekitarnya, dimana jarak antar bangunan di lingkungan tersebut sangatlah rapat kurang lebih $1 \mathrm{~m}$. Pada sisi kiri lahan (dilihat dari sisi timur) terdapat bangunan gedung dengan tinggi $\pm 15 \mathrm{~m}$ yang difungsikan sebagai kost-kostan. Pada sisi lainya terdapat rumah tinggal sekaligus difungsikan sebagai kost-kostan. Pada depan lahan yang dibatasi jalan dengan lebar $\pm 4 \mathrm{~m}$ terdepat deretan rumah tinggal dengan ketinggian rata-rata $5 \mathrm{~m}$ dan jarak antar bangunan yang rapat $( \pm 1 \mathrm{~m})$.

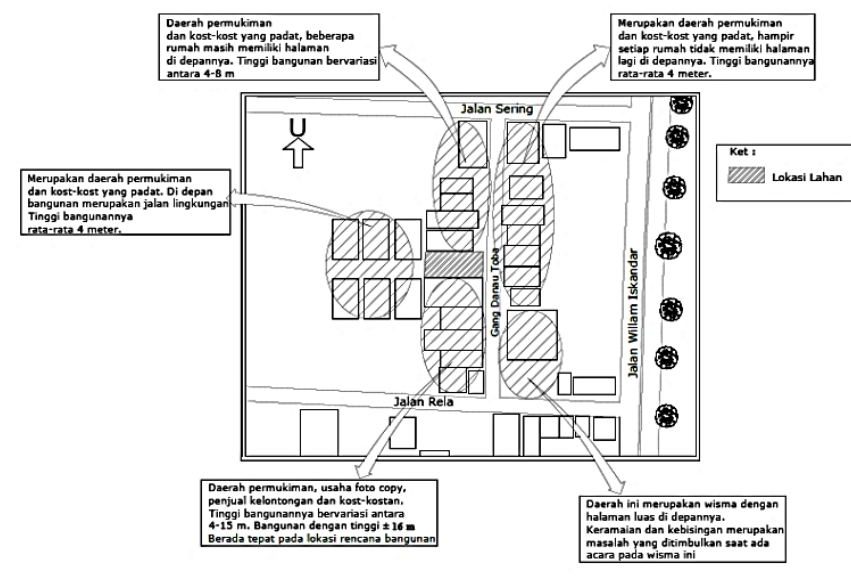

\section{Gambar 12 Kondis site existing}

\subsection{Hasil Analisa}

Dari data yang telah dipaparpakan didapat hasil analisa berupa berapa ruang yang dibutuhkan dalam rumah tersebut, orientasi bangunan, tipe bukaan yang digunakan, orientasi bukaan, berikut lebih detailnya pemaparannya.

Hasil analisa penghuni menjuru pada kebutuhan ruang, berikut detailnya :
a. Ruang Tamu : 1 unit
b. Ruang Keluarga : 1 unit
c. Ruang Tidur : 3 unit
d. Ruang Belajar : 1 unit
e. Dapur : 1 unit
f. Kamar Mandi : 3 unit
g. Ruang Makan : 1 unit

Selanjutnya adalah hasil analisa dari peredaran matahari untuk rujukan menentukan orientasi bangunan, orientasi bukaan, serta tipe bukaan yang ideal untuk pencahayaan alami. Berikut merupakan analisa radiasi matahari yang memberikan dampak positif dan dampak negatif serta solusinya bagi bangunan yang direncanakan sesuai dengan lokasi dan kondisi tapak yang ada : 
a. Dampak Positif

1) Sumber pencahayaan alami yang memadai sepanjang hari pada tapak yang berada sejajar tepat pada lintasan matahari.

2) Bangunan akan mendapatkan cahaya matahari pagi yang baik bagi kesehatan, dikarenakan pada sisi timur lahan tidak berbatasan langsung pada bangunan yang dapat menghalangi cahaya matahari.

3) Cahaya yang berasal dari arah utara dan selatan lebih soft dan stabil sepanjang hari.

b. Dampak Negatif

1) Cahaya matahari sore dari arah barat memiliki radiasi panas matahari yang cukup tinggi yang berpotensi meningkatkan suhu ruangan sehingga menimbulakan ketidaknyamanan termal.

2) Penyinaran dari sisi selatan tidak dapat maksimal diterima oleh banguan dikarenakan ada bangunan tinggi $( \pm 15$ $\mathrm{m})$ yang menghalangi cahaya dari langit selatan.

c. Solusi

1) Orientasi bangunan dibuat memanjang arah timur-barat dengan bidang timur dan barat sekecil mungkin untuk mengurangi paparan radiasi matahari secara langsung.

2) Orientasikan bukaan/jendela sebanyak mungkin ke arah selatan ataupun utara, pada arah ini cahaya mataharinya soft dan stabil sepanjang hari.

3) Bukaan/jendela yang dibuat pada sisi timur-barat diberikan sun shader/kanopi untuk mengurangi masuknya radiasi matahari secara langsung pada ruangan.

4) Membuat clesrestory window, yaitu bukaan cahaya vertikal pada fasad bangunan dengan posisi jauh dari bidang kerja di atas jendela, yang difungsikan untuk membantu perolehan cahaya pada ruang.

5) Menambahkan/menanam vegetasi untuk menyaring radiasi matahari yang masuk ke dalam bangunan.

6) Membuat kolam disekitar rumah untuk memberikan efek dingin pada ruang sekitar.
Pada daerah dengan iklim tropis lembap, angin merupakan solusi untuk menjaga suhu pada bangunan/ruang. Angin akan memanfaatkan kelembapan yang tinggi pada ruangan dengan penguapan sehingga memberikan efek dingin bagi penghuni bangunan. Berikut merupakan analisa angin yang akan memberikan panduan dalam mendesain bukaan untuk memaksimalkan ventilasi alami :

a. Dampak Positif

1) Kecepatan angin pada tapak cukup kencang, yang dapat mendukung perolehan kenyaman termal pada ruangan.

2) Pergerakan angin yang datang dari arah utara dan selatan pada siang hari akan berbelok berlawan arah dikarenakan adanya bangunan eksisting yang tinggi pada sisi selatan lahan.

3) Keberadaan jalan yang memanjang pada sisi timur lahan memberikan sirkulasi udara yang baik.

b. Dampak Negatif

1) Angin bergerak dari arah utara ke selatan (siang hari) dan sebaliknya (malam hari), dengan adanya bangunan eksisting pada sisi utara akan mengurangi potensi pergerakan angin pada sisi tersebut.

2) Pada waktu tertentu kecepatan angin bisa berlebihan, sehingga menimbulkan ketidaknyamanan termal.

c. Solusi

1) Memaksimalkan ventilasi pada sisi utara dan selatan untuk memanfaatkan arah pergerakan angin.

2) Posisikan ventilasi secara menyilang agar lebih memaksimalkan pergerakan udara pada ruangan.

3) Menggunakan tipe bukaan/jendela yang dapat memaksimalkan masuknya angin ke dalam bangunan, seperti tipe awning/hopper, jendela ayun, jendela berporos (pivot window), dan jendela jalusi.

4) Memberikan penghalang atau penyaring angin yang terlalu deras, berupa penanaman pohon pada sisi selatan. 
5) Membuat bukaan/ventilasi bawah untuk mengatasi kelembapan yang tinggi pada ruangan.

6) Membuat lubang angin (ventilasi) pada atap, untuk mengeluarkan udara panas yang terdapat diantara atap dan plafon. Hal ini dapat membantu mengurangi suhu dalam ruangan.

7) Memberikan ruang/jarak rencana bangunan dengan bangunan eksisting di sampingnya, untuk memberikan sirkulasi udara yang baik.

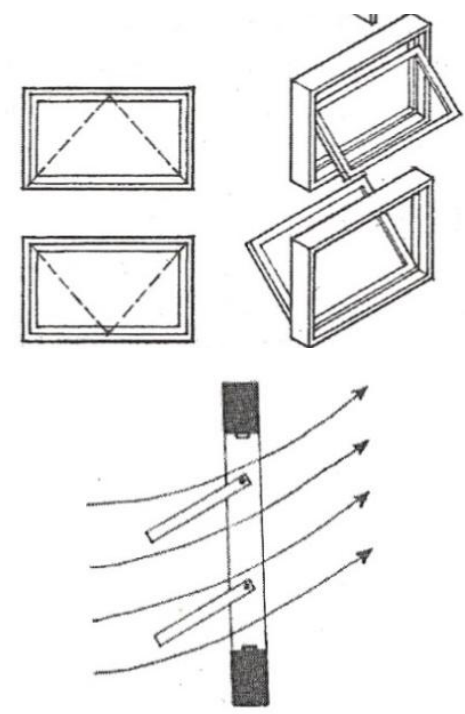

Gambar 13 Jendela tipe awning dan hopper

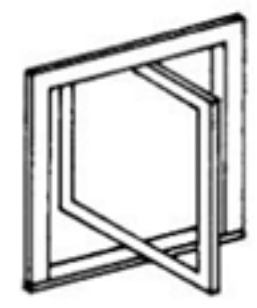

Gambar 14 Jendela tipe berporos ditengah (vipot center)

\subsection{Konsep dan Perhitungan}

\subsubsection{Organisasi Ruang}

Organisasi ruang diperlukan utuk memberikan kenyamanan saat beraktivitas di dalamnya. Beberapa faktor dasar yang perlu diketahui sebelum mengorganisasikan ruang seperti mengetahui pelaku kegitan, menjabarkan aktivitas yang ada, dan merumuskan kebutuhan ruang.

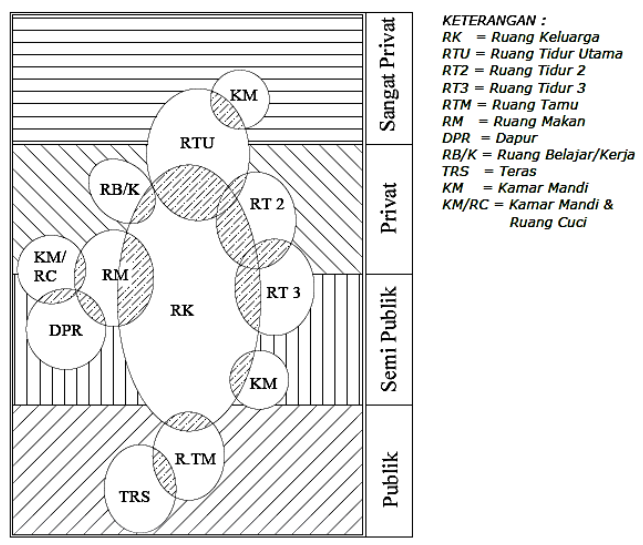

Gambar 14 Penzonaan ruang berdasarkanprivasi penghuninya

\subsubsection{Orientasi Bangunan dan Bukaan}

Kondisi lahan yang berbentuk persegi panjang akan disikapi dengan bangunan yang berbentuk persegi panjang juga, depan bangunan menghadap timur dan belakang bangunan menghadap barat. Konsep ini juga sangat baik untuk ventilasi silang.

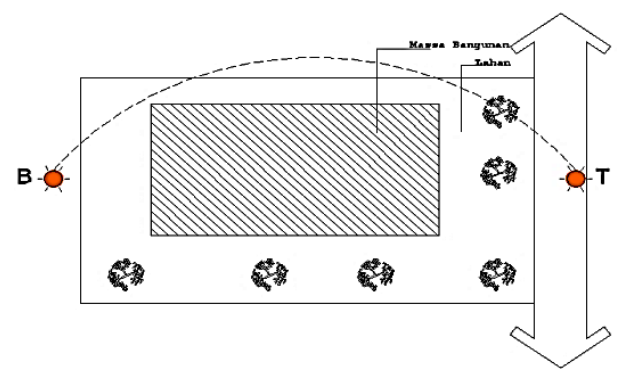

\section{Gambar 15 Orientasi Bangunan}

Bukaan yang diorientasikan menghadap selatan dan utara, akan mengahasilkan cahaya yang lebih softnamun stabil sepanjang hari. Bukaaan yang menghadap barat perlu diminimalkan untuk menghindari paparan sinar matahari sore yang tinggi.

Tabel 1 Orientasi ruang dan bukaan pada rumah tinggal terkait penerimaan cahaya

\begin{tabular}{||c|c|c||}
\hline \hline Jenis Ruang & $\begin{array}{c}\text { Cahaya } \\
\text { Ideal }\end{array}$ & $\begin{array}{c}\text { Orientasi } \\
\text { Bukaan }\end{array}$ \\
\hline \hline Ruang Tidur & Pagi & TGR s/d TL \\
\hline
\end{tabular}




\begin{tabular}{|c|c|c|}
\hline $\begin{array}{l}\text { Kamar mandi, } \\
\text { gudang }\end{array}$ & 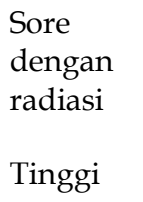 & $\mathrm{B}$ atau $\mathrm{T}$ \\
\hline $\begin{array}{l}\text { Ruang keluarga, } \\
\text { ruang } \\
\text { makan, ruang tamu }\end{array}$ & $\begin{array}{l}\text { Aktivitas } \\
\text { tinggi, } \\
\text { cahaya } \\
\text { hangat }\end{array}$ & $\mathrm{U}$ atau $\mathrm{S}$ \\
\hline $\begin{array}{l}\text { Dapur, ruang } \\
\text { belajar/ } \\
\text { kerja }\end{array}$ & $\begin{array}{l}\text { Radiasi } \\
\text { minimal }\end{array}$ & $\mathrm{U}$ dan $\mathrm{S}$ \\
\hline
\end{tabular}

Keterangan :

- TGR : Tenggara

- TL : Timur Laut

- B : Barat

- T : Timur

- U : Utara

- S : Selatan

\subsubsection{Bukaan dan Ventilasi}

Pada dasarnya bukaan dan ventilasi adalah satu kesatuan yang berfungsi mensirkulasikan udara segar dan sebagai akses masuknya cahaya pada bangunan. Kebutuhan ventilasi pada sebuah ruang adalah $10 \%-20 \%$ luas rungan tersebut, idealnya $15 \%$ dari luas ruangan tersebut. Untuk pencahayaan alami luas bukaan cahayanya adalah $1 / 8-1 / 5$ luas rungan tersebut, idealnya $1 / 7$ dari luas ruangan tersebut.

Konsepnya adalah membuat bukaan/jendela yang mampu memberikan ventilasi yang baik sekaligus menjadi akses masuknya cahaya matahari sebagai sumber pencahayaan alami. Berikut merupakan rekapitulasi hasil perhitungan kebutuhan bukaan pada setiap ruang:

Tabel 2 Kebutuhan luas ventilasi di setiap ruangan

\begin{tabular}{||l|c|c|}
\hline \hline Fungsi Ruang & Lr & Lv \\
& $\left(\mathrm{m}^{2}\right)$ & $\left(\mathrm{m}^{2}\right)$ \\
\hline
\end{tabular}

\begin{tabular}{|c|c|c|}
\hline Ruang Keluarga & 19,13 & 4,75 \\
\hline Ruang Tamu & 10,50 & 6,82 \\
\hline Ruang Makan & 9,75 & 4,06 \\
\hline Ruang Tidur Utama & 12,00 & 2,70 \\
\hline Ruang Tidur 2 & 9,00 & 3,00 \\
\hline Ruang Tidur 3 & 9,75 & 4,80 \\
\hline KM 1 & 3,00 & 0,40 \\
\hline KM 2 & 2,50 & 0,40 \\
\hline KM 3 & 2,63 & 0,48 \\
\hline Dapur & 8,25 & 5,06 \\
\hline Ruang B & 6,00 & 3,17 \\
\hline
\end{tabular}

Keterangan :

Lr $\quad$ : Luas Ruangan $\left(\mathrm{m}^{2}\right)$

Lv : Luas Ventilasi $\left(\mathrm{m}^{2}\right)$

Berikut perhitungan luas bukaan minnimal dalam suatu ruangan, dengan catatan luas bukaan yang dihitung adalah bukaan yang benar-benar bisa ditembus cahaya tanpa halangan (menggunakan kaca) baik itu cahaya langsung maupun cahaya tidak langsung. 
Tabel 3 Kebutuhan bukaan untuk pencahayaan alami dalam ruang

\begin{tabular}{|c|c|c|c|}
\hline & $\begin{array}{c}\text { Luas } \\
\text { Ruang }\end{array}$ & KBM & $\begin{array}{c}\text { Luas } \\
\text { Bukaan }\end{array}$ \\
\hline $\begin{array}{l}\text { Fungsi } \\
\text { Ruang }\end{array}$ & $\left(\mathrm{m}^{2}\right)$ & $\begin{array}{c}{[1 / 8 x} \\
\mathrm{Lr}]\end{array}$ & Desain \\
\hline & & $\left(\mathrm{m}^{2}\right)$ & $\left(m^{2}\right)$ \\
\hline $\begin{array}{l}\text { Ruang } \\
\text { Keluarga }\end{array}$ & 19,13 & 2,39 & 2,77 \\
\hline $\begin{array}{l}\text { Ruang } \\
\text { Tamu }\end{array}$ & 10,50 & 1,31 & 4,97 \\
\hline $\begin{array}{l}\text { Ruang } \\
\text { Makan }\end{array}$ & 9,75 & 1,22 & 3,21 \\
\hline $\begin{array}{l}\text { Ruang } \\
\text { Tidur } \\
\text { Utama }\end{array}$ & 12,00 & 1,50 & 1,57 \\
\hline $\begin{array}{l}\text { Ruang } \\
\text { Tidur } 2\end{array}$ & 9,00 & 1,13 & 1,87 \\
\hline $\begin{array}{l}\text { Ruang } \\
\text { Tidur } 3\end{array}$ & 9,75 & 1,22 & 4,45 \\
\hline KM 1 & 3,00 & 0,38 & 0,40 \\
\hline KM 2 & 2,50 & 0,31 & 0,40 \\
\hline KM 3 & 2,63 & 0,33 & 0,48 \\
\hline Dapur & 8,25 & 1,03 & 4,63 \\
\hline $\begin{array}{l}\text { Ruang } \\
\text { Belajar }\end{array}$ & 6,00 & 0,75 & 1,35 \\
\hline
\end{tabular}

Keterangan :

JP : Jumlah Penghuni (orang)
KMB : Kebutuhan minimal bukaan untuk pencahayaan alami dalam ruang

4.4 Desain Rumah dan Bukaan

4.4.1 Layout dan Tampak Bangunan

Pada dasarnya bukaan dan ventilasi adalah satu kesatuan yang berfungsi mensirkulasikan.

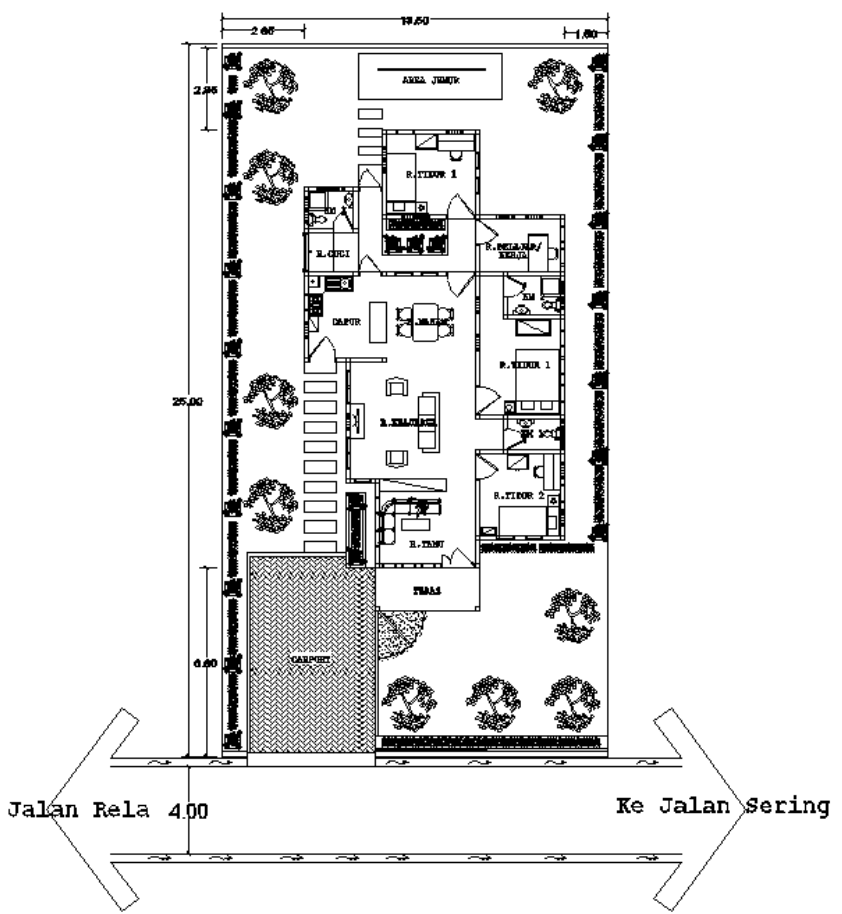

Gambar 15 Denah rumah tinggal

Tinggi bangunan dibuat dengan tinggi 4,2 $\mathrm{m}$, untuk atap tertinggi 3,5 $\mathrm{m}$. Taman mini dengan ukuran $2 \times 1,5 \mathrm{~m}$ ditempatkan diantara kamar tidur 3 dan ruang makan. Akses masuk ke dalam rumah dibuat sebanyak tiga jalur, pertama dari halaman depan langsung menuju ruang tamu, kedua dari samping menuju dapur, dan yang ketiga dari halaman belakangan menuju taman. 


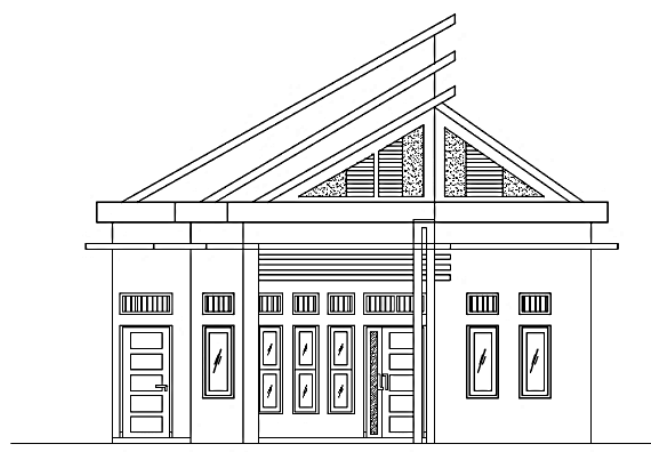

Gambar 16Tampak depan

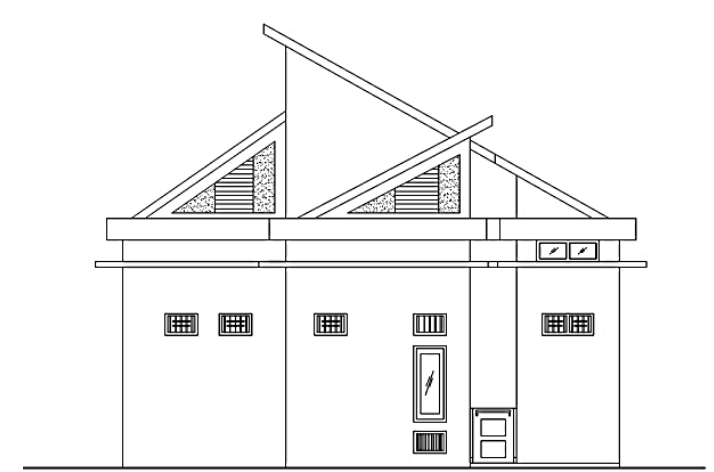

Gambar 17 Tampak belakang

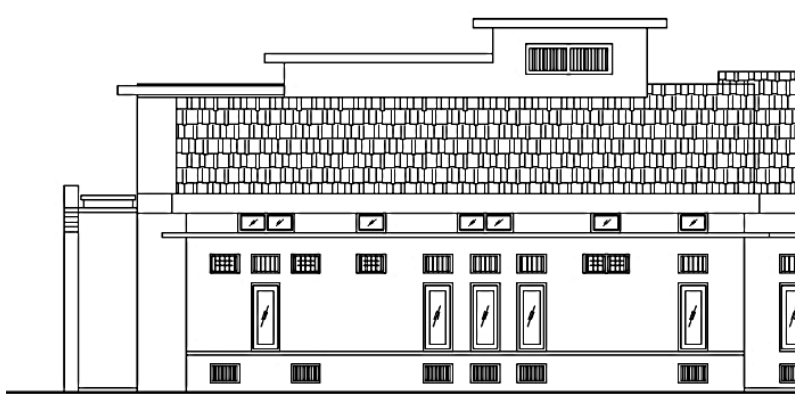

Gambar 18 Tampak samping kanan

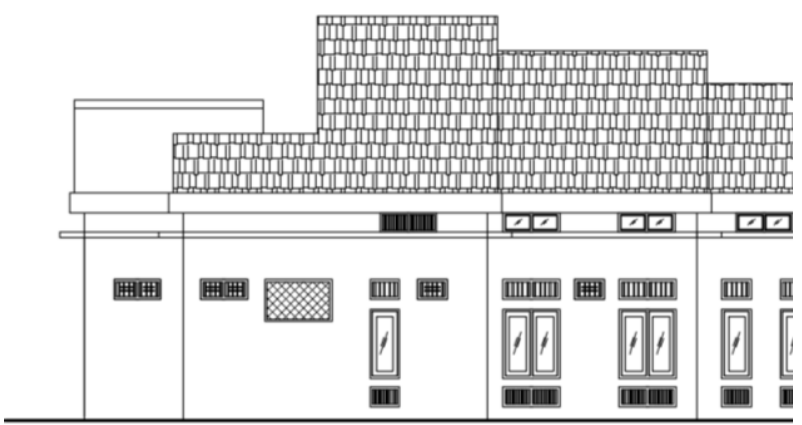

Gambar 19 Tampak samping kiri

\subsubsection{Bukaan dan Ventilasi}

Berikut merupakan desain bukaan untuk ventilasi alami sekaligus pencahayaan alami yang ditempatkan sedemikian rupa pada ruangan.

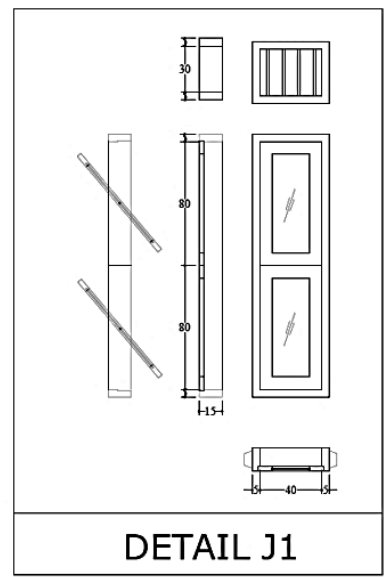

Gambar 20 Desain jendela tipe J1

Jendela tipe J1, J2 dan tipe J3 merupakan jendela tipe berporos (pivot) dengan engsel berada ditengah kusen. Jendela membuka dan menutup dengan cara diputar 90 derajat vertikal. Arah pergerakan udara dapat dipilih sehingga pengahawaan alami bisa lebih optimal.

Glazing(yang terpasang pada sash jendela) terbuat dari lembaran kaca bening yang dapat ditembus cahaya matahari tanpa ada hambatan, sehingga kebutuhan ruang akan pencahayaan alami dapat terpenuhi.

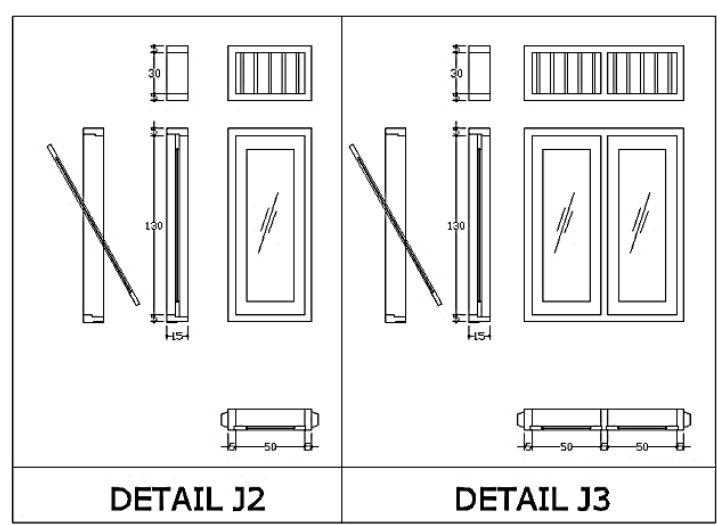

Gambar 21 Desain jendela tipe J2 dan J3 


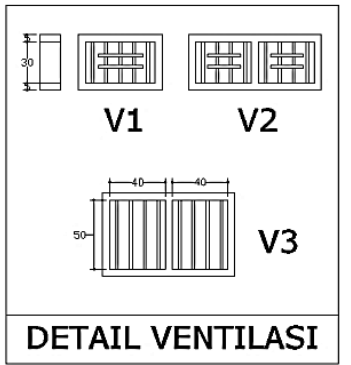

\section{Gambar 22 Desain ventilasi V1, V2, dan V3}

Ventilasi bawah merupakan ventilasi yang ditempatkan di jendela. Ventilasi ini dibuat dengan tujuan memaksimalkan pengeluaran udara lembap yang tinggi di dalam ruangan. Angin yang masuk dari ventilasi bawah selanjutnya akan membawa udara lembap ke luar ruangan melalui ventilasi atas.

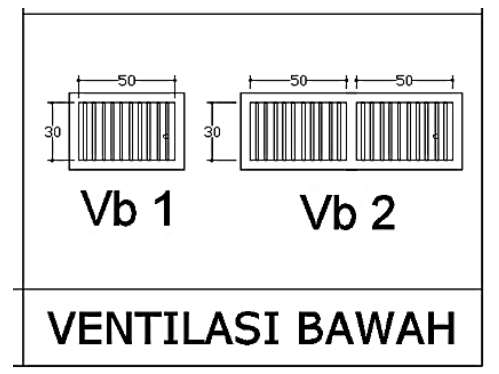

\section{Gambar 23 Desain ventilasi bawah}

\section{KESIMPULAN DAN SARAN}

\subsection{Kesimpulan}

Berdasarkan hasil pembahasan dan kaitannya dengan landasan teori, penulis dapat menarik beberapa kesimpulan mengenai desain rumah tinggal yang ramah lingkungan untuk iklim tropis di antaranya adalah sebagai berikut:

a. Desain bukaan yang sesuai dengan dengan iklim tropis terutamanya iklim tropis lembab adalah jendela tipe berporos (pivot window). Tipe ini selain berperan sebagai ventilasi yang mampu mensirkulasikan udara secara maksimal, juga berperan sebagai akses masuknya cahaya matahari sebagai sumber pencahayaan alami dengan catatan daun jendela terbuat dari kaca bening. Selain itu, pada rumah tinggal ramah tinggal juga harus diberikan jarak lahan dengan batas bangunan eksisting untuk memberi sirkulasi udara yang baik dan maupun akses masuknya cahaya ke dalam ruamah.

b. Kriteria desain bangunan agar dapat menunjang kenyamanan termal diantaranya adalah pertama orientasi bangunan terbaik untuk iklim tropis adalah arah timur-barat dan orientasi bukaan terbaik adalah arah selatan dan utara, yang kedua luas bukaan/ventilasi diusahakan semaksimal mungkin untuk memaksimalkan masuknya cahaya matahari alami dan angin, tanpa menimbulkan ketidaknyamanan termal, ketiga bila terjadi masalah ketidaknyamanan termal setelah desain bukaan dibuat, lakukan komproni desain dengan pemberian sun shader/kanopi atau sun filter pada bukaan, ke empat perbanyak vegetasi dengan tata letak yang sedemikian rupa dan kurangi perkerasan pada lahan.

\subsection{Saran}

Agar dilakukan penelitian lanjutan yang lebih konfrehensif dan kaitannya dengan pencapaian hasil yang lebih optimal yaitu meliputi :

a. Bagi pembaca, yang ingin membangun rumah tinggal yang ramah lingkungan perlu mempertimbangkan beberapa faktor, di antaranya faktor iklim (suhu, kelembapan, kecepatan angin, lamanya penyinaran matahari dalam satu hari) dan kondisi lingkungan (tapak) setempat. Faktor-faktor tersebut akan diterapkan dalam mendesain rumah tinggal (bukaan/ventilasi), sehingga fungsi rumah sebagai tempat bernaung dari iklim luar yang ekstrim dapat tercapai dan nyaman untuk dihuni.

b. Buatlah desain bukaan yang dapat memenuhi dua kebutuhan sekaligus, yakni ventilasi alami untuk sirkulasi udara yang baik dan sistem pencahayaan alami untuk kebutuhan cahaya pada siang hari.

\section{Daftar Pustaka}

Amin, C., dkk. (2013). Denah Rumah Pilihan. Jakarta: Griya Kreasi.

Ching F. D.K dan Adams C. (2008). Ilustrasi Konstruksi Gedung, Edisi Ketiga. 
(Terjemahan Tim Arsitektur ITB). Jakarta: Penerbit Erlangga. Buku asli diterbitkan tahun 2001.

Frick, H. dan Suskiyatno, B. (1998). Dasar-dasar Eko-Arsitektur, Konsep Arsitektur Berwawasan Lingkungan Serta Kualitas Kontruksi dan Bahan Bangunan untuk Rumah Sehat dan Dampaknya Atas Kesehatan Manusia. Yogyakarta: Kanisius.

Istiqomah, S, H. dan Hanas, C.W. (2011). Penyehatan Permukiman. Yogyakarta: Gosyen Publishing.

Karyono, T. H. (2013). Arsitektur dan Kota Tropis Dunia Ketiga, Suatu Bahasan Tentang Indonesia. Jakarta: PT. Rajagrafindo Persada.

Lechner, N. (2007). Heating, Cooling, Lighting: Metode Desain untuk Arsitektur. (Terjemahan Siti Handjarinto). Jakarta: PT. Rajagrafindo Persada. Buku asli diterbitkan tahun 2001.

Lippsmeier, G. (1997). Bangunan Tropis. (Terjemahan Syahmir Nasution). Jakarta: Penerbit Erlangga.Buku asli diterbitkan tahun 1980.

Manurung, P. (2012). Pencahayaan Alami dalam Arsitektur. Yogyakarta: Penerbit ANDI

Peraturan Menteri Negara Lingkungan Hidup No. 8 Tahun 2010 tentang Kriteria dan Sertifikasi Bangunan Ramah Lingkungan. Jakarta:

Wicaksono, A. A. (2009). Menciptakan Rumah Sehat. Jakarta: Griya Kreasi.

Dora, P. E. dan Nilsari, P. F. (2011). Pemanfaatan Cahaya Alami Pada Rumah Tinggal Tipe Townhouse di Surabaya. Surabaya: 